\title{
DOES GREEN ACCOUNTING MATTER TO THE PROFITABILITY OF FIRMS? A CANONICAL ASSESSMENT
}

\author{
Amaechi Patrick Egbunike and Godsday Edesiri Okoro* \\ Nnamdi Azikiwe University, Awka, Anambra State, Nigeria
}

Quite a few studies have argued that green accounting does matter to the profitability of a firm; however, little is known about Nigerian firms. To address this gap, this paper seeks to investigate whether green accounting matters to the profitability of Nigerian firms or not. Towards achieving this, an expo-facto research design was adopted and ten non-consumer goods firms listed on the Nigerian Stock Exchange were selected during 2012-2016. The data were sourced from the annual reports and accounts of the selected non-consumer goods firms. The data comprised of green accounting (expenses of community involvement and the amount spent on environmental protection) and profitability (return on equity and Tobin Q) indicators. The data obtained were analyzed by using canonical correlations. The study revealed that there was no significant relationship between green accounting and profitability measures among the non-consumer goods firms. The implication is that whether or not firms engage in green accounting, their profitability level remains unchanged. In addition, this provides evidence that the practice of green accounting among non-consumer goods firms in Nigeria is still at its ad-hoc stage. On the basis of the above findings, we proposed that the Financial Reporting Council of Nigeria and corporate entities should, as a matter of fact, accommodate the growing awareness in green accounting and formulate a disclosure requirement aimed at improving the profitability of firms. This will no doubt enhance green accounting practices among firms and in general policies aimed at enhancing their competitiveness in the industry in which they are domiciled.

Keywords: green accounting, return on equity, expenses on environmental protection and employee safety, canonical correlation

JEL Classification: M41, M48

\section{INTRODUCTION}

Green accounting as a concept is up-and-coming in developing countries like Nigeria, but has received

\footnotetext{
* Correspondence to: G. E. Okoro, Nnamdi Azikiwe University, Awka, Anambra State, Nigeria; e-mail: edesirioracle@yahoo.com
}

considerable attention in western countries, such as the United States of America (USA), the United Kingdom (UK), Italy, Spain and a lot of others. In Nigeria, several environmental and protection laws have been enacted by the Federal Government in order to ensure that furs comply with the environmentrelated matters and that the same is reported in their 
annual reports and accounts. In spite of the effort by the Government and the other agencies regulating environmental activities in Nigeria, firms, especially those in the oil and gas sector, as well as the firms in the non-consumer goods sub-sector that are involved in environmental pollution, still do not comply with these environment protection laws. As observed by D. E. Emeakponuzo and M. Udih (2015), the noncompliance by firms in Nigeria with the environmentrelated matters and the disclosure of the same in their annual reports and accounts may be connected with decay in the infrastructure, deficiencies in the suitable technology and the regulatory framework, as well as a high level of corruption. In addition to non-compliance by firms in Nigeria, the absence of appropriate green accounting models or techniques has also compounded the problems of the applicability of green accounting in Nigeria (Jeroh \& Okoro, 2016).

According to D. M. Makori and A. Jagongo (2013), green accounting refers to the practice of providing accurate information (in firms' annual reports and accounts) on the probable social costs emanating from production externalities upon the environment and how many deliberate intervention costs have been incurred in order to bridge the gap between marginal social and private costs. It is becoming an imperative that, in order for corporate firms to develop greencost responsiveness, they should disclose such green costs in their annual reports and accounts (Hoje, Kim \& Park, 2014; Ezejiofor, Racheal \& Chigbo, 2016). The disclosure of a firm's green costs is believed to make the firm responsive (Shelly, Fust \& Lisa, 2007; Cortez \& Cudia, 2011; Muller, Mendelsohn \& Nordhaus, 2011); a firm is given a chance to minimize its costs in the medium- and long-term (Hasan \& Hakan, 2012), and it is also the fundamental determinant of profitability/ performance (Lee, Pati \& Roh, 2011; Okoye \& Ezejiofor, 2013; Jeroh \& Okoro, 2016).

Quite a few studies have argued in support of a positive association between green accounting and the level of profitability (Wiseman, 1982; Edwards, 1998; Agbiogwu, Ihendinihu \& Okafor, 2016; Nnamani, Onyekwelu \& Ugwu, 2017); however, there are still arguments to the contrary that green accounting negatively affects the level of profitability (Makori \&
Jagongo, 2013; Adekanmi, Adedoyin \& Adewole, 2015; Dibia \& Onwuchekwa, 2015). The dissimilar findings may have led to inconclusive results with respect to green accounting and profitability indicators. Also, firms in the non-consumer goods sub-sector cause a lot of environmental problems. This study has been motivated by the inconclusive nature of the studies carried out on green accounting and profitability indicators in the Nigerian corporate environment.

In light of the foregoing, the goal of this paper is geared towards assessing whether or not green accounting does matter to the profitability of firms in Nigeria.

In this paper, we have hypothesized that there is no significant canonical correlation between green accounting and the profitability of non-consumer goods firms.

Besides, the scientific instrument is the secondary data comprising of expenses of the community involvement, the amount spent on environmental protection, return on equity and Tobin Q. The remaining part of this paper is divided into the following sections: the prior literature, the theoretical framework, materials/methods, results, discussion and conclusion.

\section{LITERATURE REVIEW}

There is robust empirical evidence of green accounting and the performance of firms in developed and developing countries. In Nigeria, the largest number of the pieces of empirical evidence were obtained from the oil and gas industry, whereas there are scanty empirical studies conducted by using the non-consumer goods sub-sector. For instance, J. N. Nnamani et all (2017) evaluated the effect of sustainability accounting on the financial performance of the listed manufacturing firms in Nigeria. These manufacturing firms were those belonging to the brewery sub-sector. The secondary data were obtained from the annual reports and accounts of the three brewery firms quoted on the Nigerian Stock Exchange for the total asset, return on 
equity, the total personal cost to turnover and return on assets, and the data obtained were analyzed by using the ordinary least square estimation technique. The study found that sustainability reporting had a positive and significant effect on the financial performance of the brewery companies that had been subjected to investigation.

E. Jeroh and G. E. Okoro (2016) assessed the effect of environmental and dismantling costs on a firm's performance among the selected oil and gas companies in Nigeria. The data on return on assets, and the environmental and dismantling costs were obtained from the annual reports and accounts of the selected oil and gas companies during 2008-2015 and were analyzed via the ordinary least square. The findings of the study were indicative of the fact that environmental and dismantling costs positively influenced the performance of a firm. In addition, the moderating variable (the size of a firm) was found to have a negative and significant influence on the performance of a firm.

A. A. Agbiogwu, J. U. Ihendinihu and M. C. Okafor (2016) analyzed the impact of environmental and social costs on the performance of manufacturing companies in Nigeria by using the secondary data obtained from the ten randomly selected companies' annual reports and accounts in 2014, and the t-test statistical tool was employed in the analysis of those data. The findings showed that environmental and social costs significantly affect the net profit margin, earnings per share and return on capital employed.

R. A. Ezejiofor et all (2016) examined the effect of sustainability accounting on the performance of corporate firms in Nigeria. The ex-post-facto research design was employed and the secondary data were sourced from annual reports and accounts. The regression statistical technique was adopted in testing the relevant hypotheses of the study. Based on the analysis of the data, it was revealed that the environmental cost has no significant impact on the revenue of corporate firms. However, a positive relationship was established. In addition, the environmental cost significantly and positively influences the profit generation of corporate firms in Nigeria.
J. C. Eze, A. U. Nweze and C. I. Enekwe (2016) identified the factors affecting environmental accounting in developing nations by means of employing both primary and secondary data. The survey approach was the selected research design. However, the study found that environmentally friendly companies which voluntarily disclose their environmental activities benefit from a high level of competitiveness. Their findings also suggest that environmental accounting stimulates companies to track their greenhouse gas emissions and other environmental elements against the reduction or elimination point.

A study by D. E. Emeakponuzo and M. Udih (2015) of environmental accounting practices and corporate firms in Nigeria revealed that, in order to develop a suitable Environmental Management System (EMS), the role played by the plant environmental staff was fundamental and that such plant environmental staff should work in collaboration with accountants in order to ensure a suitable EMS. In addition, the findings revealed that attention had not been paid to the cost of natural resource damages in the project evaluation. The above study utilized twenty-five quoted companies from dissimilar sectors. The hypotheses of the study were tested via the Chi-square and Kendall coefficients. More specifically, based on the test of the hypotheses, the study found that environmental accounting practice was significant in benchmarking the standard for corporate reporting and that compliance with the environmental protection laws in Nigeria might not have had a significant influence on environmental accounting practice due to enlightenment, enforcement and compliance issues.

N. B. Ijeoma (2015) investigated the environmental practices of Nigeria's firms so as to ascertain if companies in Nigeria were environmentally friendly. The primary data were obtained through a questionnaire and the Mann-Whitney U-test was used in analyzing the data. The results showed that environmental cost accounting positively influenced the level of profitability among manufacturing firms in Nigeria. Also, it was revealed that manufacturing firms incorporated the environmentally friendly practices. 
A. D. Adekanmi et all (2015) explored the determinants of the socio-environmental accounting of the listed firms in Nigeria. The secondary data were collected from the fifty firms listed on the Nigerian Stock Exchange during the period 2005-2013. The descriptive and inferential statistics were employed in the analysis of the data, which was performed by applying the ordinary least square estimation technique. However, the study revealed that the size of the firm firm $(t=10.3263 ; \mathrm{p}<0.05)$, its profitability $(t=7.6913 ; p<0.05)$ and the number of the analysts analyzing the firm $(t=2.4684 ; p<0.05)$ were the three fundamental factors that had a positive effect on the socio-environmental reporting of the listed firms in Nigeria. In addition, socio-environmental performance had a significant $(t=-3.3508 ; \mathrm{p}<0.05)$ negative influence on socio-environmental reporting in the Nigerian quoted companies.

N. O. Dibia and J. C. Onwuchekwa (2015) empirically analyzed the determinants of the environmental disclosures in the oil and gas industry in Nigeria. The study variables were the size of the firm, its profit, leverage, the audit firm type and environmental disclosures. The cross-sectional design was adopted and a sample of fifteen companies was drawn from the oil and gas industry. These oil and gas companies were those quoted on the Nigerian Stock Exchange during the period 2008-2013. The binary regression technique was employed in the analysis of the data. The finding suggests that there is a significant association between the size of the firm and corporate socially responsible disclosures. No significant relationship was accounted for with respect to the profit, leverage, audit type and corporate socially responsible disclosures, either.

R. Namakonzi and E. Inanga (2014) explored the extent to which Environmental Management Accounting (EMA) was applied, as well as the costs and challenges militating against the implementation process of EMA, so as to achieve effective environmental management in the Ugandan manufacturing industry. The study employed the descriptive approach and the primary data were basically relied upon. The study found that the greatest challenges militating against the implementation of EMA in Uganda were connected with the difficulties in defining, unraveling, recognizing, categorizing, measuring and controlling environmental protection costs in Uganda.

The study of D. M. Makori and A. Jagongo (2013) established whether there was any significant association between environmental accounting and the profitability of the selected firms. The data for the study were obtained from the annual reports and accounts of the fourteen companies quoted on the Bombay Stock Exchange in India and the analysis was carried out via multiple regressions. The study found that there was a significant negative association between environmental accounting and return on capital employed, whereas a significant and positive association was established for earnings per share, the net profit margin and a dividend per share.

A similar study of environmental accounting and organizational performance among the oil and gas companies operating in the Niger Delta Region of Nigeria was conducted by B. E. Bassey, S. O. Effiok and O. E. Eton (2013). The primary and secondary data were obtained and Pearson's Product Moment Correlation Coefficient (PPMCC) was the statistical tool employed. The study found that the environmental cost significantly correlated with a firm's profitability.

M. S. K. Ifurueze, M. E. Lydon and P. F. Bingilar (2013) assessed the effect of the environmental cost on the corporate performance of the oil companies in the Niger Delta Region of Nigeria. Twelve oil and gas companies were sampled and the secondary data (return on equity, the community development cost, the waste management cost and the employee health and safety cost) were obtained and analyzed. In order to test the relevant hypotheses of the study, the multiple regression technique was employed. The findings of the study suggest that sustainable business practices and corporate performance are significantly correlated. Also, the study revealed that the possible reasons for corporate conflict resolution as witnessed in a reduction in the fines, penalties and compensations paid to host communities in the Niger Delta Region of Nigeria might be connected with the sustainability practices of the oil and gas companies in that region. 
Based on the review of the prior studies, it is obvious that there are dissimilar findings leading to inconclusive results with respect to green accounting and profitability indicators. Thus, this study was carried out with an aim of providing the empirical evidence that may either disapprove or prove the prior results related to the relationship between green accounting and profitability indicators in Nigeria.

\section{THE THEORETICAL FRAMEWORK}

The theoretical foundation of this paper is anchored in the "Stakeholder Theory". This theory sees corporate organizations as the elements of the social system, while concentrating on the diverse stakeholder groups within a society. The emphasis of this theory is on the fact that stakeholders need to be identified by corporate organizations in order for such organizations to ascertain the groups that need to be managed so as to enhance the interest of the organization. In this case, the interest of stakeholders will be that of maximizing the wealth of the owners of resources and being environmentally responsible. Thus, the management of corporate organizations needs to manage these interests in order for them to become environmentally friendly towards the environment in which the business is domiciled.

Summarily, the stakeholder theory illustrates how certain activities which corporate organizations are engaged in can be sustained without undermining the interest of resource owners and the environment. Thus, this theory recognizes that, in order for corporate organizations to maintain a good relation, the interest of all stakeholders must not be infringed or undermined.

This paper tries to investigate the relationship between these green accounting indicators (the expenses of community involvement and the value spent on environmental protection) and the profitability (return on equity and tobinq) of nonconsumer goods firms in Nigeria. Given the number of the independent and dependent variables, the study employed the Multivariate Correlation Analysis (MCA) and, more specifically, the study utilized the Canonical Correlation Analysis (CCA).

\section{DATA AND METHODS}

This paper seeks to investigate green accounting and the profitability of non-consumer goods firms in Nigeria. In order to achieve this, the expo-facto research design was adopted. This design is concerned with the data that are in existence. This design was employed since it seeks to establish the factors that are connected with the already existing events, where the researcher has no control over certain variables as the events already exist and cannot be manipulated. The study population comprised of all of the listed non-

Dependent Variables

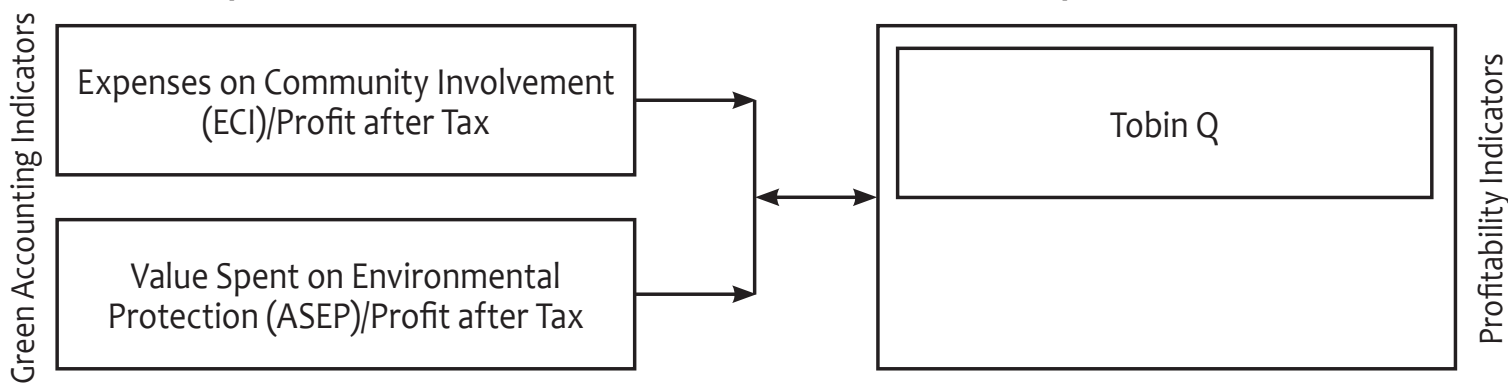

Figure 1 The Conceptualized Model of the Study 
consumer goods firms quoted on the Nigerian Stock Exchange. However, a purposive sampling technique was employed to select the ten non-consumer goods firms that have a consistent dataset and have captured environmental data in their annual reports and accounts during the period under investigation. The data were employed from the annual reports and accounts of the selected non-consumer goods firms from 2012-2016.

The data comprised of the green accounting (the expenses of community involvement and the amount spent on environmental protection) and the profitability (return on equity and tobinq) indicators. In order to avoid the heteroscedasticity problem, the green accounting indicators were scaled by Profit after Tax (PAT) in order to assume a similar "value range". The appropriate method of data analysis is the canonical correlations since it can be used to assess the association among the groups or sets of variables: the green accounting variables (X1) and the sets of the profitability variables (X2). The analysis was done via STATA 13.0.

\section{RESULTS}

Table 1 reports the descriptive statistics of the profitability measures (tobing and retoe: return on equity) and the green accounting measures (eci: the expenses of community involvement and asep: the amount spent on environmental protection) for the non-consumer goods firms studied. In the Table 1, tobinq has a mean of 6.17 and a standard deviation of .5492. The mean value of retoe is 6.90 with a standard deviation approaching 1.27; eci has a mean of 6.22 of the total profit and a standard deviation of .8659 , whereas asep has a mean of 8.17 of the total profit and a standard deviation approaching .9052.

From Table 2 above, it is obvious that the mean VIF for all of the variables does not exceed the standardized Variance Inflation Factor (VIF) level $(1.12<10.0)$. The implication is that there is the absence of multicollinearity among the variables. Consequently, there is the absence of the heteroscedasticity problem among the variables.
Table 1 The Descriptive Statistics of the Variables

\begin{tabular}{l|lllll}
\hline Variable & Obs & Mean & Std. Dev. & Min & Max \\
\hline tobinq & 50 & 6.1728 & .5492222 & 5.02 & 6.98 \\
retoe & 50 & 6.8982 & 1.267823 & 5.14 & 9.56 \\
eci & 50 & 6.2212 & .8658596 & 5.06 & 8.76 \\
asep & 50 & 8.1682 & .9052244 & 6.01 & 9.2 \\
\hline
\end{tabular}

Source: Authors

Table 2 The Variance Inflation Factor Result

\begin{tabular}{l|cc}
\hline Variable & VIF & 1/VIF \\
\hline retoe & 1.12 & 0.895922 \\
tobinq & 1.12 & 0.895922 \\
Mean VIF & 1.12 & \\
\hline
\end{tabular}

Source: Authors

From Table 3, it can be seen that eci (1.1969) was found to be the most significant green accounting variable, followed by asep (0.1484). In addition, the result revealed that when other variables are held constant, a one-unit increase in the eci will result in a 1.1969 increase in the score on the first canonical variate in the green accounting measures set. In the same way, when other variables are held constant, a one-unit increase in the asep will result in a 0.1484 increase in the score on the first canonical variate in the green accounting measures set. A similar circumstance occurred in the score of the second canonical variate in the green accounting measures set, although a negative sign is attached to them.

Table 3 The Canonical Correlation Result of the Raw Coefficients for the Green Accounting Variable Set

\begin{tabular}{l|cc}
\hline & 1 & 2 \\
\hline eci & 1.1969 & -0.2548 \\
asep & 0.1484 & -1.1610 \\
\hline
\end{tabular}

Source: Authors 
In Table 4, it was shown that retoe (0.7903) was found to be the most significant profitability variable, followed by tobing $(-0.0110)$. However, in the score of the second canonical variate, tobinq was found to be the most significant profitability measure with the value of 1.9236 and a negative sign was attached to retoe (-0.2643). This implies that when other variables are held constant, a one-unit increase in tobinq will result in a 1.9236 increase in the score on the second canonical variate in the profitability measures set.

Table 4 The Canonical Correlation Result of the Raw Coefficients for the Second Profitability Variable Set

\begin{tabular}{l|cc}
\hline & 1 & 2 \\
\hline tobinq & -0.0110 & 1.9236 \\
retoe & 0.7903 & -0.2643 \\
\hline
\end{tabular}

Source: Authors

The result in Table 5 revealed that tobinq (0.3750) and retoe $(0.0177)$ have a positive connection with the sets of the green accounting variables (eci and asep).

Table 5 The Canonical Correlation

\begin{tabular}{cc}
\hline \multicolumn{2}{c}{ Canonical correlation } \\
\hline 0.3750 & 0.0177 \\
\hline
\end{tabular}

Source: Authors

The tests of significance for all of the canonical correlations as presented in Table 6 revealed that the statistics in relation to Wilks' Lambda, Pillai's Trace and Lawley-Hotelling trace f-statistics and the P-values showed clearly that there was no significant relationship between the profitability measures (tobing and retoe) and those of the green accounting measures (eci and asep). However, Roy's Largest Root suggests a significant relationship between the profitability measures and those of the green accounting measures. Overall, it implies that there is no significant relationship between profitability and the green accounting measures among the nonconsumer goods firms in Nigeria.
Table 6 The Tests of Significance for all Canonical Correlations

\begin{tabular}{l|ccccc}
\hline & Statistic & $\mathrm{df} 1$ & $\mathrm{df} 2$ & $\mathrm{~F}$ & prob>F \\
\hline $\begin{array}{l}\text { Wilks' } \\
\text { lambda }\end{array}$ & .85913 & 4 & 92 & 1.8141 & $0.1328 \mathrm{e}$ \\
$\begin{array}{l}\text { Pillai's } \\
\text { trace }\end{array}$ & .140914 & 4 & 94 & 1.7812 & $0.1391 \mathrm{a}$ \\
$\begin{array}{l}\text { Lawley- } \\
\text { Hotelling } \\
\text { trace }\end{array}$ & .163917 & 4 & 90 & 1.8441 & $0.1273 \mathrm{a}$ \\
$\begin{array}{l}\text { Roy's } \\
\text { largest } \\
\text { root }\end{array}$ & .163604 & 2 & 47 & 3.8447 & $0.0284 \mathrm{u}$ \\
\hline & $\mathrm{e}=$ exact, a = approximate, $\mathrm{u}=$ upper bound on $\mathrm{F}$
\end{tabular}

Source: Authors

\section{CONCLUSION}

Search for environmental sustainability has caused corporate organizations to realize that there is the need to disclose the green costs resulting from the combined effects of social and environmental damages in their annual reports and accounts. Perhaps, the necessity to disclose green costs in the annual reports and accounts of firms has prompted a series of studies of the need to assess whether green accounting affects the profitability of firms in Nigeria globally. In this paper, we gauged green accounting by means of the expenses of the community involvement and the amount spent on environmental protection, and profitability via return on equity and Tobin Q. The study period spanned from 2012 to 2016 and a multivariate statistical tool (canonical correlation) was employed in the analysis of the data. On the basis of the statistical test, it was revealed that the expenses of the community involvement were the most significant green accounting measure in the score on the first and second canonical variates. Contrarily, return on equity was found to have the most significant score on the first canonical variate, whereas Tobin $Q$ had the most significant score on the second canonical variate in the profitability measures set. 
The canonical variate results suggest that a large number of firms in Nigeria spend a lot of resources on the community involvement, more than on environmental protection. Perhaps, the rationale why firms spend a large amount of resources on the community involvement rather than on environmental protection may be connected with the belief that the corporate image of organizations can be improved by their becoming involved in the community development programs in the environment where their firms are domiciled. Besides, the outcome of the tested hypothesis has showed that green accounting has no significant canonical correlation with the profitability of non-consumer goods firms as is indicated in Wilk's Lambda, Pillai's Trace, Lawley-Hotelling trace f-statistics and P-values. This implies that, in spite of the fact that firms do engage in green accounting, their profitability level remains unaffected.

The finding of this study is at variance with prior empirical evidence that green accounting significantly affects the profitability of firms in Nigeria. On this note, it was recommended that the Financial Reporting Council of Nigeria (FRCN), the regulatory framework of accounting and management of firms should accommodate the growing awareness in green accounting and as a matter of urgency, the FRCN and regulatory framework of accounting should devise a disclosure requirement aimed at enhancing the profitability level of firms in Nigeria. Moreover, this study has contributed to the literature indicating that green accounting does not matter to the profitability of firms, especially those operating with non-consumer goods in Nigeria. As a matter of fact, this study was limited to non-consumer goods firms in Nigeria; hence, future research studies should take into account an investigation into green accounting and the profitability of consumer-goods and healthcare firms in Nigeria.

\section{REFERENCES}

Adekanmi, A. D., Adedoyin, R. A., \& Adewole, J. A. (2015). Determinants of socio-environmental reporting of quoted companies in Nigeria. Journal of Research in Business, Economics and Management, 4(4), 459-471.

Agbiogwu, A. A. Ihendinihu, J. U., \& Okafor, M. C. (2016). Impact of environmental and social costs on performance of Nigerian manufacturing companies. International Journal of Economics and Finance, 8(9), 173-180. doi.org/10.5539/ijef. v8n9p173

Bassey, B. E., Effiok, S. O., \& Eton, O. E. (2013). The impact of environmental accounting and reporting on organizational performance of selected oil and gas companies in Niger Delta Region of Nigeria. Research Journal of Finance and Accounting, 4(3), 57-73.

Cortez, M. A. A., \& Cudia, C. P. (2011). Sustainability and firm performance: A case study of Japanese Electronics Companies. Institute of International Relations and Area Studies, Ritsumeikan University, 10(1), 322-339.

Dibia, N. O., \& Onwuchekwa, J. C. (2015). Determinants of environmental disclosures in Nigeria: A case study of oil and gas companies. International Journal of Finance and Accounting, 4(3), 145-152. doi:10.5923/j.ijfa.20150403.01

Edwards, D. (1998). The link between company environmental and financial performance. London, UK: Earthscan Publications Ltd.

Emeakponuzo, D. E., \& Udih, M. (2015). Environmental accounting practices by corporate firms in emerging economies: Empirical evidence from Nigeria. Advances in Research, 3(2), 209-220. doi:10.9734/AIR/2015/12829

Eze, J. C., Nweze, A. U., \& Enekwe, C. I. (2016). The effects of environmental accounting on a developing nation: Nigerian experience. European Journal of Accounting, Auditing and Finance Research, 4(1), 17-27.

Ezejiofor, R. A., Racheal, J., \& Chigbo, B. E. (2016). Effect of sustainability environmental cost accounting on financial performance of Nigerian corporate organizations. International Journal of Scientific Research and Management, 4(8), 4536-4549. doi:10.18535/ijsrm/v4i8.06 
Hasan, Ş., \& Hakan, Ö. (2012). The importance of environmental accounting in the context of sustainable development and within IFRS evaluation. International Symposium on Sustainable Development, May 31-June 01 2012, Sarajevo: Federation of Bosnia And Herzegovina.

Hoje, J., Kim, H., \& Park, K. (2014). Corporate environmental responsibility and firm performance in the financial services sector. Korea Advanced Institute of Science and Technology, Working Paper, Series No. 2014-007.

Ifurueze, M. S. K., Lydon, M. E., \& Bingilar, P. F. (2013). The impact of environmental cost on corporate performance: A study of oil companies in Niger Delta States of Nigeria. Journal of Business and Management, 2(2), 1-10. doi. org/10.12735/jbm.v2i2p01

Ijeoma, N. B. (2015). Evaluation of companies environmental practices in Nigeria. Social and Basic Sciences Research Review, 3(7), 349-364.

Jeroh, E., \& Okoro, G. E. (2016). Effect of environmental and dismantling costs on firm performance among selected oil and gas companies in Nigeria. Sahel Analyst: Journal of Management Sciences, 14(5), 14-26.

Lee, J. W. G., Pati, N., \& Roh, J. J. (2011). Relationship between corporate sustainability performance and tangible business performance: Evidence from oil and gas industry. IJBIT, $3(3), 72$.
Makori, D. M., \& Jagongo, A. (2013). Environmental accounting and firm profitability: An empirical analysis of selected firms listed in Bombay Stock Exchange, India. International Journal of Humanities and Social Science, 3(18), 248-256.

Muller, N. Z., Mendelsohn, R., \& Nordhaus, W. (2011). Environmental accounting for pollution in the United States economy. American Economic Review, 101(5), 16491675. doi:10.1257/aer.101.5.1649

Namakonzi, R., \& Inanga, E. (2014). Environmental management accounting and environmental management in manufacturing industries in Uganda. African Journal of Economic and Sustainable Development, 3(4), 288-329. doi:10.1504/AJESD.2014.065578

Nnamani, J. N., Onyekwelu, U. L., \& Ugwu, O. K. (2017). Effect of sustainability accounting and reporting on financial performance of firms in Nigeria brewery sector. European Journal of Business and Innovation Research, 5(1), 1-15.

Okoye, P. V. C., \& Ezejiofor, R. A. (2013). An appraisal of sustainability environmental accounting in enhancing corporate productivity and economic performance. International Journal of Advanced Research, 1(8), 685-693.

Shelly, F., Fust, L., \& Lisa, W. (2007). Corporate sustainability initiatives: The next TQM? Korn/Ferry International

Wiseman, J. (1982). An evaluation of environmental disclosures made in corporate annual reports. Accounting, Organizations and Society, 7(1), 53-63. doi.org/10.1016/03613682(82)90025-3.

Received on $15^{\text {th }}$ February 2018, after revision, accepted for publication on $23^{\text {rd }}$ April 2018.

Published online on $26^{\text {th }}$ April 2018. 
Amaechi Patrick Egbunike obtained his PhD at the Department of Accountancy, Faculty of Management Sciences, Nnamdi Azikiwe University, Awka, Nigeria. His field of study is Accounting, with research interests in Management Accounting, Earnings Management and Forensic Accounting.

Godsday Edesiri Okoro obtained his MSc degree at the Department of Accountancy, Faculty of Management Sciences, Nnamdi Azikiwe University, Awka, Nigeria. His field of study is Accounting, with research interests in Corporate Reporting, Earnings Management and Financial Management.

\title{
DA LI JE EKOLOŠKO RAČUNOVODSTVO VAŽNO ZA PROFITABILNOST PREDUZEĆA? KANONIČKA PROCENA
}

\author{
Amaechi Patrick Egbunike and Godsday Edesiri Okoro \\ Nnamdi Azikiwe University, Awka, Anambra State, Nigeria
}

Veliki broj autora u svojim studijama zastupa stav da je ekološko računovodstvo važno za profitabilnost preduzeća. Međutim, malo se zna o nigerijskim preduzećima. Da bismo razmotrili ovaj jaz, u ovom radu želimo da istražimo da li je ekološko računovodstvo važno za profitabilnost nigerijskih preduzeća. U tom smislu, usvojili smo expo facto model istraživanja i odabrali deset preduzeća koja se ne bave proizvodnjom robe široke potrošnje, a koja se kotiraju na Nigerijskoj berzi u periodu 2012-2016. Godišnji izveštaji i računi odabranih preduzeća koja se ne bave proizvodnjom robe široke potrošnje bili su naši izvori podataka. Podaci su se sastojali od indikatora ekološkog računovodstva (troškovi uključivanja zajednice i visina sredstava potrošenih na zaštitu životne sredine) i profitabilnosti (povraćaj na kapital i TobinQ). Dobijeni podaci analizirani su upotrebom kanoničkih korelacija. Ova studija otkriva da ne postoji značajna veza između ekološkog računovodstva i mera profitabilnosti među preduzećima koja se ne bave proizvodnjom robe široke potrošnje. Bez obzira na to da li preduzeća pribegavaju ekološkog računovodstvu ili ne, implicitno se može zaključiti da nivo profitabilnosti tih preduzeća ostaje nepromenjen. Pored toga, na osnovu istraživanja, pokazali smo da je praksa ekološkog računovodstva među preduzećima koja se ne bave proizvodnjom robe široke potrošnje $u$ Nigeriji još uvek $u$ ad hoc fazi. Na osnovu formulisanih stavova, smatramo celishodnim da se Veće za finansijsko izveštavanje Nigerije i korporativni subjektima prilagode rastućoj svesti o potrebi uvođenja ekološkog računovodstva i da formulišu zahteve za saopštavanje podataka u cilju poboljšanja profitabilnosti preduzeća. To će, nesumnjivo, poboljšati računovodstvene prakse među preduzećima, kao i opšte politike, u cilju povećanja konkurentnosti tih preduzeća u industriji u kojoj posluju.

Ključne reči: ekološko računovodstvo, povraćaj na kapital, troškovi zaštite životne sredine i bezbednosti zaposlenih, kanonička korelacija 